\title{
Autoimmunity in Chagas' heart disease
}

\author{
Immunology Laboratory of Transplantation, Heart Insitute, Hospital das Clínicas,
} Faculdade de Medicina da Universidade de São Paulo - São Paulo, Brazil

\begin{abstract}
The time scale dissociation between high parasitemia and tissue pathology, allied to the absence of parasites in the heart lesions of chronic Chagas' disease cardiopathy, casted doubt on the direct participation of Trypanosoma cruzi in tissue lesions. Moreover, the heart tissue lesions in chronic Chagas' disease cardiopathy are associated to an inflammatory mononuclear cell infiltrate, presumably the ultimate effectors of tissue damage. It has been hypothesized that the inflammatory cell infiltrate could mediate a delayed hypersensitivity process directed to the heart tissue components, an autoimmune response triggered by immunological cross-reactivity in the course of a protective immune response against some T.cruzi antigen homologous to heart proteins. However, little is known about the efector role of the T cells in the infiltrate, or about the nature of the antigen that lead to their accumulation in tissue. In this paper, we will review the published evidence on autoimmunity and immunological cross-reactivity between $T$. cruzi and the mammalian host, along with data generated in our laboratory. The definition of the precise role played by autoimmunity in the pathogenesis of Chagas' disease cardiopathy may have important consequences both for immunoprophylaxis and for the therapeutic approach of chronic Chagas' disease.
\end{abstract}

UNITERMS: Chagas' disease. Autoimmunity.

\section{INTRODUCTION}

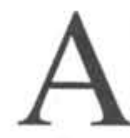

lthough many studies suggest the existence of autoimmune phenomena in chronic Chagas' disease cardiomyopathy (CCC), the actual pathogenetic role played by autoimmunity is still largely

\author{
Address for correspondence: \\ Laboratório de Imunologia de Transplantes \\ Instituto do Coração, Hospital das Clínicas da Faculdade \\ de Medicina da Universidade de São Paulo \\ Av. Dr. Enéas de Carvalho Aguiar, 500 3․ andar \\ São Paulo - SP - Brasil - CEP 05403-000
}

unknown. The heart lesions that are hallmark of chronic Chagas' disease occur decades after the initial infection episode, in a subset (ca. 30\%) of infected individuals. The lesions are associated to a diffuse lymphocytic infiltrate, presumably the ultimate mediator of tissue damage. The scarcity of parasites in damaged areas - a finding incompatible with the notion that heart lesions result from hypersensitivity to parasite antigens - prompted early investigators to suggest that the inflammatory heart lesion could be of "auto-allergic", or autoimmune, nature. According to such an autoimmunity/antigenic mimicry hypothesis, lymphocytes in the heart should recognize and mount delayed-type hypersensitivity responses towards a tissue-specific heart component bearing structural similarities to a given $T$. cruzi antigen. However, little is known about the effector role of tissue-infiltrating T cells, 
or about the antigen triggering their accumulation in heart. tissue. In this paper, we will review the literature on autoimmunity and antigenic mimicry/immmunologic cross-reactions between Trypanosoma cruzi and host tissue in Chagas'disease, apart from discussing data obtained in our own laboratory. The definition of the pathogenetic role of autoimmunity may have important implications in immunoprophylatic and immunomodulatory therapeutical approaches in CCC.

\section{CURRENT CONCEPTS IN AUTOIMMUNITY}

Humoral or cellular immune responses to a given protein antigen in most cases depend on the initial recognition of the antigen in question by $\mathrm{CD} 4+\mathrm{T}$ lymphocytes. $\mathrm{T}$ cells only recognize antigen when it is physically associated to the membrane of a macrophage or a B cell. These cells break or "process" the antigen molecule into smaller fragments or peptides, which are placed inside a "groove" at the outer part of an HLA class II molecule (e.g. HLA-DR, -DQ, -DP). The antigenic peptide-HLA molecule complex is exported to the cell membrane, where it can interact with the antigen receptor of an antigen-specific T cell. Each T cell is capable of recognizing only a single antigenic fragment, or epitope, from a single protein, via its unique antigen receptor. This receptor binds to the HLA-epitope complex via its variable region, very much like immunoglobulins interact with antigens. The recognition of its specific epitope leads the $\mathrm{CD} 4+\mathrm{T}$ cell into activation, with production and secretion of multiple lymphokines and interleukins - immunological mediators able to mobilize and control other types of cells involved in the immune response. Depending upon the lymphokines produced, the subsequent immune response may specialize into the humoral or cellular arms.

Each individual recognizes distinct regions (epitopes) of a given antigen molecule. This is so because HLA molecules, which bind the antigenic peptides, vary among individuals - and precisely in the regions lining the antigenic peptide-binding "groove", resulting in the presentation of distinct HLA-related repertoires of discrete epitopes to the immune system. Thus, different individuals may or may not recognize a given epitope, and this. difference is often genetically determined by the HLA. As there are up to 100 different alleles for some HLA loci, this implies a wide diversity of recognition repertoires in the population.
The specificity of the immune response may allow an attack to infectious agents, for instance, without damaging the host's own tissue - the so-called self-nonself discrimination whereupon the immune system is "tolerant" to the components of the organism it belongs to (self components). There are situations, however, when the tolerance status towards a given self component is broken; it follows that the immune system recognizes and may destroy self tissues containing that component. In the organ-specific autoimmune diseases, the target self-antigen or target epitope only occurs in a single organ, leading to an organ-specific lesion. Examples of such a situation are the autoimmune thyroid diseases (Graves'/Hashimoto), multiple sclerosis and insulin-dependent diabetes mellitus, among others. The triggering mechanisms of autoimmune diseases are still largely unknown, but always involve the loss of control of self-recognizing, potentially autoaggressive $\mathrm{B}$ or $\mathrm{T}$ cells, which is many times secondary to polyclonal activation or antigenic mimicry (structural similarity between foreign and self antigens). Environmental (e.g. infections) as well as genetic (familial occurrence, HLA association) factors are known to interplay.

Facing the biological role played by HLA molecules in the genetic control of immune responses to defined antigens, the association of most autoimmune diseases with alleles of the HLA system suggest that some HLA alleles favor the recognition of self-epitopes. The presentation of a self epitope by a given HLA molecule allows the recognition by epitope-specific $\mathrm{T}$ cells, the necessary conditions for an autoimmune response. The precise identification of target epitopes in an autoimmune disease is of foremost importance for the understanding of pathogenesis, and may allow for specific immune intervention aiming at controlling tissue damage.

\section{EVIDENCE FOR AUTOIMMUNITY IN CHAGAS' DISEASE}

Ever since 1930, Torres observed an intense inflammatory infiltrate consisting of lymphocytes, mononuclear cells, plasma cells, histiocytes and granulomata in heart tissue, in the absence of parasite nests, in necropsy studies of patients who died of CCC (35). In the first experimental report suggesting the involvement of immunological factors in the pathogenesis of CCC, Muniz \& Azevedo induced inflammatory lesions in the myocardium of rhesus monkeys after inoculation with $T$. cruzi homogenates, thus postulating the participation of 
delayed-type hypersensitivity to $T$. cruzi components in the pathogenesis of CCC (20). In a histopathological mapping study of the whole heart with serial sections, $T$. cruzi was identified in only $20 \%$ of the hearts studied (16), an evidence which was in line with the pioneering observation of Torres that the heart lesion and inflammatory infiltrate had no correlation with the presence of the parasite. The histopathological picture, allied to the available experimental evidence, led several authors to postulate that heart tissue damage in CCC could be due to "auto-allergic mechanisms of delayed hypersensitivity towards myocardial components" (2), now known as autoimmune mechanisms. It was then hypothesized that the breakdown of immunological tolerance with heart tissue damage could be secondary to an originally protective response directed to a given $T$. cruzi antigen bearing structural similarities to $a$ a tissue-specific heart component. Along the following years, the autoimmunity/antigenic mimicry hypothesis was experimentally approached by many investigators.

As a corollary of the theory of autoimmune pathogenesis of CCC, several studies compared the lesions of CCC with "experimental allergic myocarditis" induced by immunization with cardiac tissue homogenate. This was repeated by Kozma et al., in rhesus monkeys (17), and by Cossio et al. in mice (7). They both observed heart lesions in immunized animals similar to experimental $T$. cruzi infection. Chambo et al. identified anti-T. cruzi antibodies in mice with experimental autoimmune myocarditis induced by immunization with heart homogenate (5).

Studies on the sensitization of peripheral blood mononuclear cells (PBMC) from CCC patients to cardiac antigens met contradictory results. Cardiac antigens induced lymphokine (MIF) production, and non-infected cardiomyocytes were targets of cytotoxicity by CCC PBMC $(11,32)$. However, cardiac homogenate did not elicit proliferative responses among $\mathrm{CCC}$ peripheral blood $\mathrm{T}$ cells (34). The absence of proliferative responses of T cells to cardiac tissue antigens put the theory of autoimmune pathogenesis of CCC under severe criticism (15).

Along the 70's and 80 's, there have been several reports of immunological cross-reactivity/antigenic mimicry between more or less defined $T$. cruzi and host antigens. Cossio et al. described antibodies present in the serum of CCC patients, capable of binding to vascular endothelium and interstitium in mice, the so-called EVI antibodies (8). Later, these antibodies were demonstrated not to recognize human cardiac tissue, and the initial findings of correlation with cardiac symptoms were not reproducible (14).

Santos-Buch et al. described anti-sarcolemma antibodies cross-reacting with $T$. cruzi membranes in sera from patients with severe CCC (28). However, patients with Dressler's syndrome or Duchenne's muscular dystrophy - diseases where there is nonspecific destruction of heart tissue - also presented such antibodies, suggesting they were secondary to heart destruction and probably played little role in pathogenesis. The immunization of mice with sarcolemmal antigens induced myocarditis, but methodological problems confused the interpretation of such a finding (1).

Levin et al. reported that sera from CCC patients possessed antibodies against an epitope of $T$. cruzi ribosomal $\mathrm{P}$ protein which is very similar to the corresponding region of mammalian ribosomal $\mathrm{P}$ protein (18). However, as ribosomal proteins are present in all cell types, they are unlikely targets for a heart-specific autoimmune attack. Later it was found that antibodies against $T$. cruzi ribosomal protein do not crossreact with the corresponding human protein. Bonfá et al. described antigenic mimicry between a $23 \mathrm{kDa}$ ribosomal protein and a corresponding mammalian protein in ca. $30 \%$ of chronic Chagas'disease patients independent of clinical presentation (4).

Searching for structural subtrates for the hypothesis that the denervation seen in Chagas' disease has immunological causes, several groups produced monoclonal antibodies displaying crossreactivity between T. cruzi and mammalian nervous tissue. Several such antibodies caused instant paralysis and lethal respiratory depression when injected into mice - a clinical picture that certainly does not match chronic Chagas' disease (23). Van Voorhis \& Eisen defined a crossreactive epitope between a $T$. cruzi flagellar protein and a neuronal $47 \mathrm{kDa}$ protein (36). However, the presence of crossreactive antibodies in patients' sera did not correlate with any clinical form of Chagas' disease.

The involvement of polyclonal $\mathrm{T}$ and $\mathrm{B}$ cell activation was carefully dissected in the murine model of acute infection by $T$. cruzi (19). Even though these results were not reproduced directly in humans, the "lymphoid" character of acute $T$. cruzi infection in humans, with the attending spleen and lymph node enlargement and production of heterophile antibodies is typical of disease situations with demonstrated polyclonal lymphocyte activation, like infectious mononucleosis. The polyclonal activation of the acute phase of Chagas' disease could eventually lead to autoimmunity by breaking down immunological tolerance to a given heart antigen. It is difficult, however, to extrapolate conclusions from the murine model to the chronic phase of human Chagas' disease, as it is known that the parasite loads in murine infections are larger and more prolonged than in human infections. 


\section{CARDIAC MYOSIN: RELEVANT SELF ANTIGEN IN THE PATHOGENESIS OF EXPERIMENTAL CCC?}

A number of the above mentioned papers raised refutable and/or inconclusive evidence for the autoimmune theory of $\mathrm{CCC}$ pathogenesis, in many cases just reporting antigenic mimicry phenomena between $T$. cruzi and host tissue, without clinico-biological correlation with $\mathrm{CCC}$ or digestive system denervation ("mega syndrome"). Kierszembaum stated that, for CCC to be considered as an organ-specific autoimmune disease (like thyroiditis, insulin-dependent diabetes mellitus, etc.), two conditions should be met: i) the identification of an organ-specific antigen, a target to immunologically mediated heart damage, and ii) the ability of $\mathrm{T}$ cells or antibodies derived from a $T$. cruzi infected animal and specific for that selfantigen, to perform passive transfer of heart lesions to a normal animal (15). A critical analysis of the literature up to the mid-80's shows that, although the histopathological findings and experimental evidence strongly suggest the role of cellular immunity to heart tissue components in $\mathrm{CCC}$, there has been only one study focusing on the T cell recognition of a partially defined muscle antigen (1).

Recently, two independent reports pointed towards an important role for heart-reactive CD4+ T lymphocytes in the pathogenesis of the murine model of CCC. Rizzo, Cunha-Neto \& Teixeira (25) demonstrated the presence of myosin-specific CD4+ T cells in mice chronically infected by $T$. cruzi. Ribeiro-dos-Santos, Menguel et al. (24) reported that CD4+ T cells reactive to heart tissue, obtained from chronically $T$. cruzi-infected mice, could mediate heart lesions when passively transferred (injected) into syngenic non-infected mice. It has been recently described that the generation of antibody against cardiac myosin $\mathrm{HC}$ is correlated to the development of chronic inflammatory cardiopathy among chronically $T$. cruzi infected mice (33). Myosin may be a prime candidate target autoantigen in CCC. Myosin heavy chain (myosin HC) is the most abundant heart protein - $50 \%$ of total protein by weight (12); moreover, the cardiac isoform of myosin is structurally distinct from other myosin isoforms, like those of skeletal or smooth muscle (38). Myosin is recognized in many situations of heart-specific autoimmunity, such as rheumatic heart disease (10) and murine post-Coxsackie virus B3 autoimmune cardiomyopathy (21). Immunization with cardiac myosin $\mathrm{HC}$ in adjuvant induces an aggressive myocarditis $(22,30)$. Taken together, these reports point to a reasonable consensus about the possible participation of cardiac myosin-reactive $\mathrm{T}$ lymphocytes in murine models of CCC. The murine models cited above fulfill the criteria defined by Witebsky et al. (37) for autoimmune diseases: the identification of an organ-specific self-antigen which induces tissue lesions when injected into a normal animal, and the reproduction of the lesion with the passive transfer of lymphocytes.

\section{ANTIGENICITY OF CARDIAC MYOSIN IN HUMAN CCC}

Even though there is reasonable information on the participation of heart-reactive $\mathrm{T}$ cells in murine models of $\mathrm{CCC}$, little is known in human disease. The establishment of human $\mathrm{CCC}$ as an organ-specific autoimmune disease depends on the confirmation of the relevance of the organspecific heart antigen recognized in murine models (i.e. myosin) among CCC patients. In order to validate myosin as a relevant heart antigen in the pathogenesis of human $\mathrm{CCC}$, we proposed the following working hypotheses, which were the conceptual framework for the investigation carried out in our laboratory:

1) The evolution to cardiomyopathy, or the permanence in the asymptomatic form, would be a consequence of differential ability of each individual to recognize - or not - a heart-specific myosin epitope, after uniform exposure to an environmental factor ( $T$. cruzi infection).

2) The mechanism of tolerance breakdown to cardiac myosin should be antigenic mimicry (structural similarity) with crossreactive recognition between myosin and a highly antigenic $T$. cruzi protein - an immunodominant antigen. The strong immune response directed to the parasite antigen should raise an immune response to the shared epitope in cardiac myosin, but only in those individuals capable of recognizing it, as described in the previous item.

3) T cells reactive against the relevant epitope in cardiac myosin should be present in the inflammatory infiltrate on heart lesions of CCC patients, which would be strongly suggestive of the involvement of such $\mathrm{T}$ cells in the immune/inflammatory response leading to progression of heart tissue damage.

\section{Antibody crossreactivity between cardiac myosin and $\mathrm{T}$. cruzi antigen MXT: clinical and biological relevance}

We probed several recombinant $T$. cruzi proteins with specific anti-myosin IgG antibodies purified from sera 
from CCC patients. One of the proteins tested was crossreactively recognized, in a specific manner, by antimyosin antibodies - and thus was called MXT protein (Myosin X T. cruzi) (figure 1). In order to confirm the finding, we tested the recognition of the T. cruzi MXT protein by anti-myosin antibodies purified individually from sera of 28 Chagasic patients (14 CCC, 14 asymptomatic). Although the test was performed in a limited number of sera, the compartmentalization of myosin-MXT crossreactive antibodies among CCC patients' sera $-100 \%$ vs. $14 \%$ among asymptomatic chagasic sera - was highly significant $(p=2.3 \times 10-6$, Fisher's exact test), as can be seen in Figure 2. In other autoimmune diseases, like insulin-dependent diabetes mellitus, the association of immunological reactivity to certain organ-specific self-antigens (e.g GAD enzyme) with the disease is taken as evidence for the involvement of its immune recognition in the pathogenesis of the disease (3). In order to investigate whether myosin-MXT crossreactive antibodies might be secondary to heart tissue destruction with extrusion of intracellular proteins like myosin, we looked for myosin-MXT crossreactive antibodies in sera from Duchenne's muscular dystrophy patients presenting degeterative cardiomyopathy without inflammatory etiology. The negative results obtained suggest that the mere exposure of cardiomyocyte intracellular proteins may not be enough to raise the production of myosin-MXT crossreactive antibodies.

The antibody crossreactivity between cardiac myosin and $T$. cruzi MXT antigen imply the sharing of similar amino acid sequences between the two proteins, a structural similarity underlying "antigenic mimicry". When the amino acid sequences of human (38) b cardiac myosin heavy chain and T. cruzi MXT protein (A. Gruber and B. Zingales, personal communication) were compared, we found a 6 amino acids-long sequence that was virtually identical in both proteins, with a single glycine-leucine substitution. Competitive inhibition assays for crossreactive antibodies established that the homologous region was indeed the cross-reactive epitope. The crossreactive epitope is located in the $\mathrm{S} 2$ region of myosin, closer to its carboxy-terminal end. Comparison of the amino acid sequence of cardiac myosin in this stretch with those of other tissue-specific isoforms of myosin, like skeletal or smooth muscle myosin, as well as cytoplasmic myosin, showed that the crossreactive epitope is only expressed in the cardiac myosin isoform, thus being heart muscle-specific. Together, these results suggest that a heart muscle-specific epitope in cardiac myosincrossreactive with $T$. cruzi MXT protein (biological relevance), may be recognized selectively by $T$. cruzi-infected individuals who develop heart disease (clinical relevance), fulfilling hypothesis number (i).

\section{Immunodominance of T. cruzi antigen MXT.}

Although myosin-MXT crossreactive antibodies were present almost exclusively in sera from CCC patients, MXT protein itself could be recognized, paradoxically, by non-fractionated sera from $100 \%$ of Chagasic patients tested, no matter whether CCC or asymptomatic. We interpreted this finding in the following way: there may be two distinct epitopes in MXT protein, only one of them in antigenic mimicry with myosin, and the other one being specific to MXT protein. We tested this hypothesis with synthetic peptides representing each epitope. Our results suggest that CCC patients' sera possess antibodies against both epitopes, while asymptomatic patients typically possess antibodies to the MXT-specific epitope (Table 1). Besides, antibodies against $T$. cruzi MXT protein may be very abundant in Chagasic sera, reaching high titers and adding up to as much as $1 \%$ or total serum immunoglobulin. These data indicate that $T$. cruzi MXT protein, which presents immunological crossreactivity with cardiac myosin, is highly immunogenic or

Table 1

Recognition of immunodominant and myosin-cross-reactive epitopes in T. cruzi MCT protein by sera from Chagas'cardiopathy (CCC) and asymptomatic seropositive (ASY) individuals.

\begin{tabular}{lccccc} 
MXT epitopes & Peptide 1 & Peptide 2 & Peptide 3 & $\begin{array}{c}\text { Peptide 4 } \\
\text { immuno-dominant }\end{array}$ & $\begin{array}{c}\text { Peptide 5 } \\
\text { myosin-homologous }\end{array}$ \\
CCC sera & - & - & - & + & + \\
ASY sera & - & - & - & + & - \\
\hline
\end{tabular}




\section{CONCENTRATION}

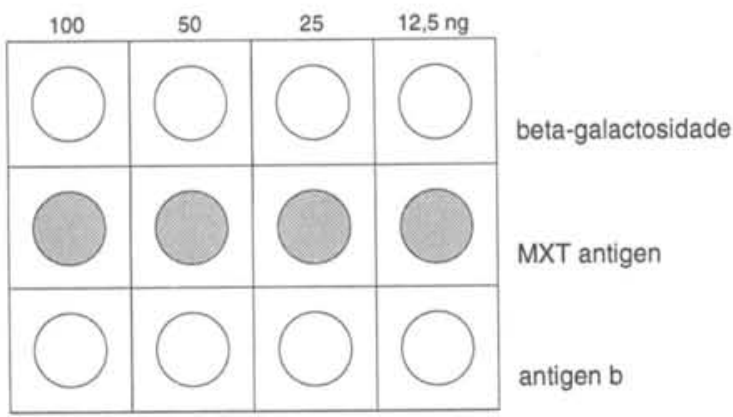

Figure 1. Anti-cardiac myosin antibodies from CCC patients display cross-reactivity with $T$. cruzi MXT protein.

immunodominant, fulfilling postulate (ii) from the working hypotheses.

\section{Identification of $T$ cell clones derived from endomyocardial biopsies from CCC patients, simultaneously recognizing cardiac myosin and T. cruzi protein MXT.}

The participation of the crossreactive antibody in the pathogenesis of CCC is unlikely. The inability to find immunoglobulin deposits onto heart fibers (14), together with the T lymphocyte-rich inflammatory infiltrate, both suggest strongly the participation of $\mathrm{T}$ cells, and not antibodies, in CCC pathogenesis. In this context, we can interpret the identification of myosin-MXT crossreactive antibodies in sera from $100 \%$ of CCC patients as a marker for the existence of CD4+ T cells with similar specificity, as is the case with most T-cell dependent antibody responses (see current concepts in autoimmunity section). Such cardiac myosin-MXT crossreactive antibodies can conceivably have an important role in CCC pathogenesis. The identification of CD4+ T cells in CCC heart lesions, crossreactively recognizing the heart-specific epitope of cardiac myosin and MXT protein (Figure 3) stands as evidence for a possible participation of cardiac myosinMXT crossreactive recognition by $\mathrm{T}$ cells in the pathogenesis of CCC, and fulfills working hypothesis

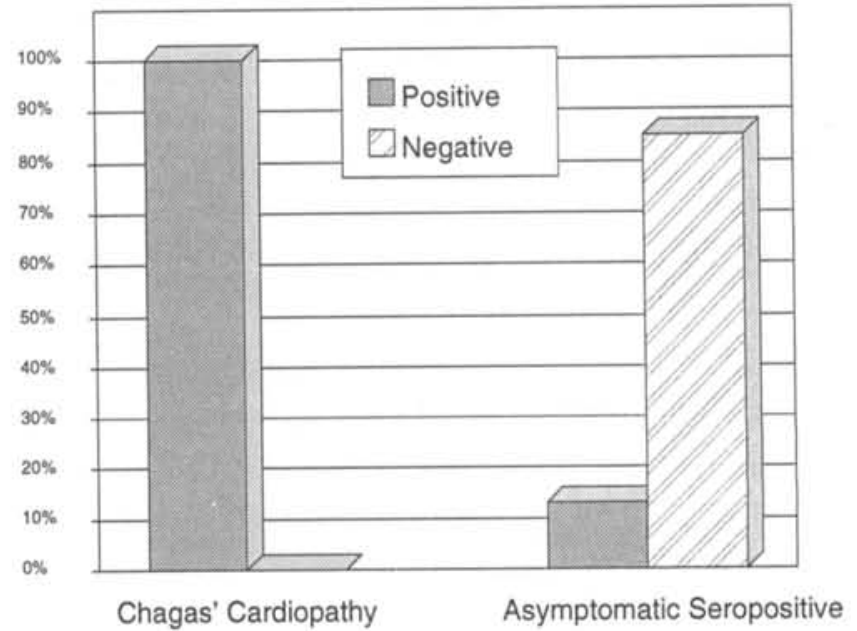

Figure 2. Prevalence of cardiac myosin-MXT crossreactive antibodies in sera from T. cruzi-infected CCC and ASY individuals.

number (iii). The isolation of $\mathrm{T}$ cells reactive against the relevant self-antigen is an important criterion in the establishment of autoimune etiology for any disease, according to the new criteria postulated by Rose \& Bona (27).

However, how could an intracellular protein like cardiac myosin become antigenic? Recently, Smith \& Allen demonstrated that interstitial macrophages from normal heart can present cardiac myosin antigenic peptides coupled to MHC class II molecules, and are capable to stimulate myosin-specific CD4+ T cells (29). The endocytosis by macrophages of myosin from heart fibers - which allows presentation of its antigenic peptides - might be linked to the "scavenger" functions of machophages upon senescent heart cells. This way, the authors could explain how myosin-specific CD4+ T cells, sensitized in the periphery after injection of cardiac myosin in the footpads of mice, could eventually recognize their target antigen in the normal heart, and thus start a process of delayed-type hypersensitivity with heart lesion, in myosininduced experimental autoimmune myocarditis.

Could the myosin-MXT crossreactive T cell clones found in heart lesions be the mediators of CCC? An analogy can be drawn with experimental autoimmune myocarditis: after sensitization in the periphery by macrophages expressing the MXT epitope in their HLA 
class II molecules as a consequence of endocytosis of $T$. cruzi, myosin-MXT crossreactive CD4+ T cells thus elicited could recognize the MXT-crossreactive epitope of cardiac myosin presented by HLA class II molecules of heart interstitial macrophages, when recirculating through the heart. On the other hand, this hypothesis is also consistent with the existence of "helper" $\mathrm{T}$ cells reactive to the cardiac myosin-MXT, necessary for the production of crossreactive antibodies. This hypothesis is displayed schematically in Figure 4. In order to confirm the role played by these $\mathrm{T}$ cell clones in the pathogenesis of CCC, it would be necessary to establish whether they are capable of producing pro-inflammatory lymphokines involved in a delayed-type hypersensitivity reaction.

\section{Absence of detectable responses from $T$ cell lines and clones obtained from endomyocardial biopsies of CCC patients to T. cruzi antigens.}

When we assayed the antigen recognition of $\mathrm{T}$ cells derived from endomyocardial biopsies from $\mathrm{CCC}$ patients, we were unable to detect any $\mathrm{T}$ cell line or clone primarily reactive to any $T$. cruzi antigen tested in our panel-four immunodominant purified $T$. cruzi antigens and a whole trypomastigote lysate. This meant testing of $22 \mathrm{~T}$ cell clones and 2 polyclonal $\mathrm{T}$ cell lines derived from three $\mathrm{CCC}$ patients. These negative results are intriguing, as in this issue Higuchi et al. demonstrated that $T$. cruzi forms, albeit still unfrequent, can be detected in CCC heart tissue areas involved in inflammatory lesions with the aid of sensitive immunochemical techniques (13). It cannot be formally excluded that an artifact of the $\mathrm{T}$ cell assay protocol, or even the immunological imbalance known to exist in T. cruzi infection (19) could be responsible for the apparent absence of proliferative response to $T$. cruzi antigens. On the other hand, it is possible that our negative finding was caused by the scarce and disperse distribution of parasites in CCC heart tissue - which by the way is common in other organs as well, as is attested by the transmission of $T$. cruzi infection by a kidney transplant from an infected donor (6). Specifically, none of the CCC patients from whom we obtained heart-derived $\mathrm{T}$ cells presented parasites in the endomyocardial biopsy fragments obtained. This seems to suggest that, at least in the areas of heart tissue free from the parasite, the direct antigenic stimulus of $T$. cruzi does not seem to be the determining event for the lymphocytic infiltrate. This does not imply, however, that the $\mathrm{T}$ cell infiltrate in heart tissue areas surrounding ruptured pseudocysts or free instersitial parasites may not be directly stimulated by $T$. cruzi antigens. On the other hand, the fact that treatment of experimentally $T$. cruzi infected rabbits with anti-T. cruzi drugs during acute phase of infection does not prevent progression to chronic cardiopathy suggests that the physical presence of $T$. cruzi has little direct participation in the pathogenesis of $\mathrm{CCC}$ (31). Furthermore, as most heart tissue in CCC patients is affected by a destructive myocarditis with a lymphocytic infiltrate in the absence of detectable T. cruzi forms, it seems reasonable to suggest that a good deal of the heart tissue lesion seen in CCC is

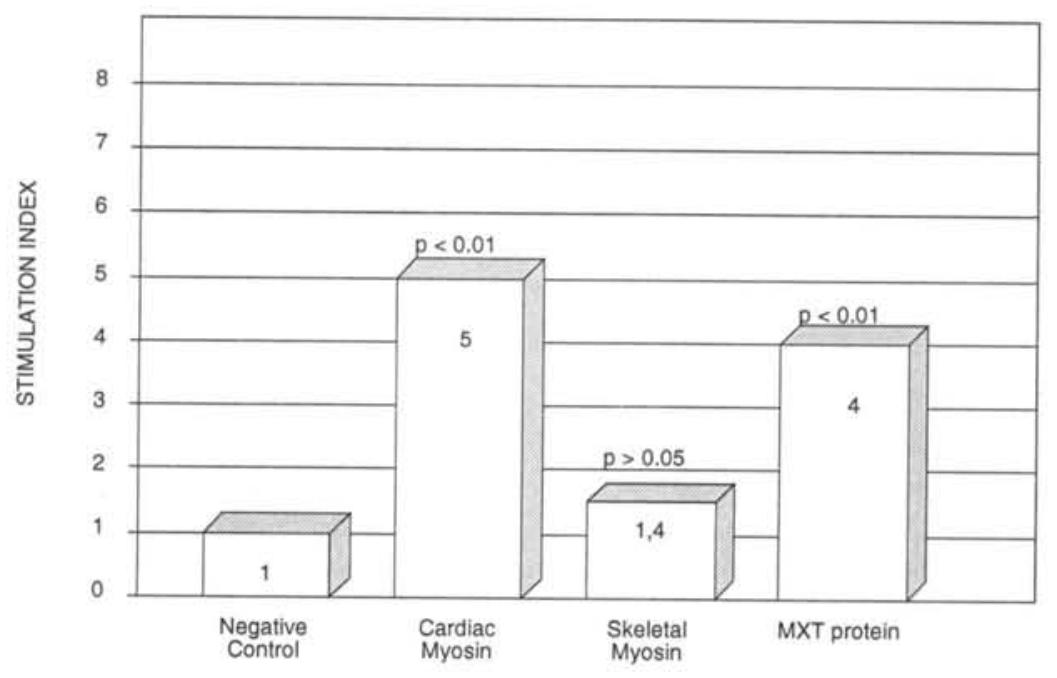

Figure 3. Proliferative response of CD4+ T cell clone E205, derived from endomyocardial biopsy from CCC patient. 


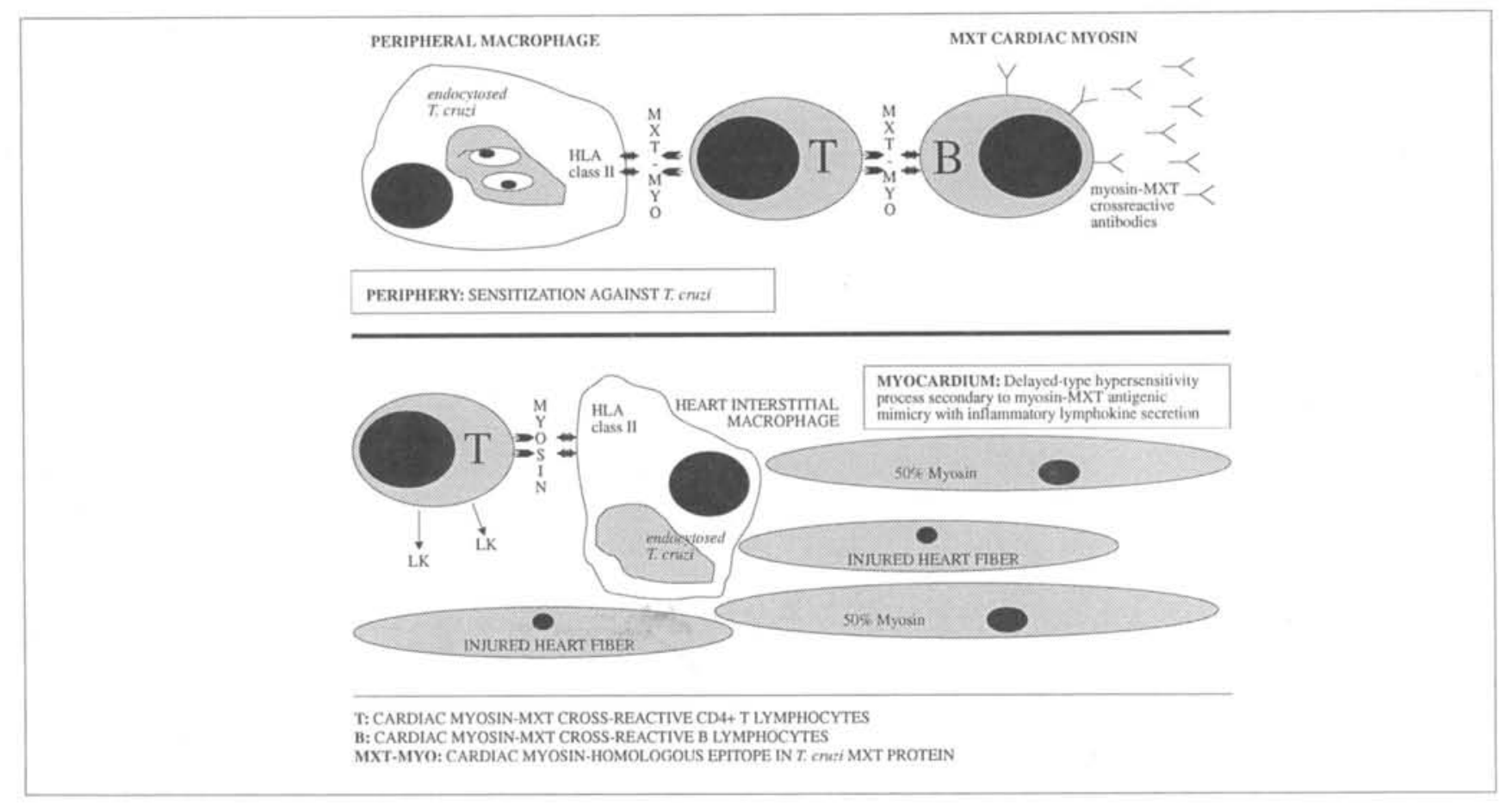

Figure 4. Participation of cardiac myosin-MXT cross-reactive CD4+ T cell clones in the pathogenesis of heart lesions in CCC.

mediated by cardiac myosin-reactive $\mathrm{T}$ cells, sensitized by antigenic mimicry with the immunodominant $T$, cruzi antigen MXT. In our model, among $T$. cruzi-infected individuals, only individuals capable of recognizing the crossreactive epitope at the humoral and $\mathrm{T}$ cell level would possess cardiac myosin-MXT crossreactive T cells able to initiate inflammatory damage to heart cells, thus being susceptible to developing CCC.

\section{PERSPECTIVES}

We molecularly identified a crossreactive epitope between human cardiac myosin and $T$. cruzi protein MXT, down to the amino acid sequence level. We established that the crossreactive epitope in cardiac myosin is a heartspecific amino acid sequence. We demonstrated that this crossreactive epitope seems to be almost exclusively recognized by $\mathrm{CCC}$ rather than asymptomatic patients, thus defining the clinical relevance of its recognition. Finally, we identified $\mathrm{T}$ cell clones derived from the heart lesion sites of CCC patients that simultaneously recognize cardiac- but not skeletal - myosin and MXT protein.

Taken together, our data seem to suggest a major role for autoimmunity in the pathogenesis of CCC. Together with the evidence in murine models, the described data may establish human CCC as a true organ-specific autoimmune disease, as the evidence for it is comparable to that supporting the autoimmune etiology of "classical" autoimmune diseases like insulin-dependent diabetes mellitus. The definition of the heart antigen relevant for the pathogenesis of an autoimmune disease is the first step for conceiving antigen-specific immunomodulation approaches in therapy, as a means to abolish the deleterious autoimmune response while leaving the protective antiparasite response intact. The first therapeutic trials of antigen-specific immunomodulation in murine and human autoimmune diseases like multiple sclerosis, rheumatoid arthritis, and uveitis have been recently published $(26,39)$. On the other hand, our findings may finally allow the search for effective subunit vaccines devoid of components of $T$. cruzi that bear the pathogenic heart-crossreactive determinants. 


\section{Resumo}

A dissociação na escala do tempo que ocorre entre os quadros de infecção aguda por Trypanosoma cruzi, que cursa com parasitemia e profusa parasitose tecidual, semanas após o contágio, e a cardiopatia chagásica crônica pobre em formas tecíduais do parasita que se manifesta décadas mais tarde, em vigência de parasitemia indetectável, levantou dúvidas sobre a participaçāo direta do T. cruzina cardiopatia chagásica crônica. Surgiu a hipótese de que o dano ao miocárdio seria secundário a um processo de hipersensibilidade retardada dirigido ao próprio tecido cardiaco, mediado pelo infiltrado inflamatório linfomononuclear universalmente associado às lesōes. Segundo essa hipótese, a resposta auto-imune dirigida ao miocárdio seria causada por reaçäo cruzada imunológica desencadeada durante a resposta imune de defesa contra algum antígeno de T. cruzi homólogo a estruturas cardiacas. Entretanto, pouco ou nada se sabe de concreto sobre papel efetor dos linfócitos do infiltrado, ou do antígeno desencadeador de seu acúmulo no tecido cardíaco. Neste trabalho, revisaremos a literatura publicada sobre auto-imunidade ou de reação cruzada imunológica na Doença de Chagas, e discutiremos os resultados obtidos em nosso laboratório. A definiçăo do papel da auto-imunidade na patogênese pode ter importantes repercussōes para a imunoprofilaxia e abordagem terapêutica da cardiopatia chagásica crônica.

\section{REFERENCES}

1. ACOSTA, A. \& SANTOS-BUCH, C. - Autoimmune myocarditis induced by Trypanosoma cruzi. Circulation 71(6): 1255-1261, 1985.

2. ANDRADE, Z. - Anatomia Patológica da Doença de Chagas. Rev Goiana Med 4: 103-119, 1958.

3. BINGLEY, P.J.; BONIFACIO, E. \& GALE, E.A.M. - Can we really predict IDDM? Diabetes 42: 213-220, 1993.

4. BONFÁ, E.; VIANA, W.; BARRETO, A.C.P.; YOSHINARI, N. \& COSSERMELLI, W. - Autoantibodies in Chagas' disease: an antibody cross-reactive with human and Trypanosoma cruzi ribosomal proteins. J Immunol 150(9): 3917-3923, 1993.

5. CHAMBO, J.G.; CABEZA MECKERT, P.M. \& LAGUENS, R.P. - Presence of anti-Trypanosoma cruzi antibodies in the sera of mice with experimental autoimmune myocarditis. Experientia 46(9): 977-9, 1990.

6. CHOCAIR, P.R.; AMATO-NETO, V.; SABBAGA, E. \& TORRECILLAS, P.H. - Aspectos clínico-diagnósticos relativos à fase aguda da doenca de Chagas, em pacientes submetidos a transplante de rim e imunodeprimidos. Rev Soc Bras Med Tropical 18: 43-45, 1985.

7. COSSIO, P.M.; BUSTUOABAD, O.; PATERNO, E.; IOTTI, R.; CASANOVA, M.B.; PODESTA, M.R.; BOLOMO, N.; ARANA, R.M. \& DE PASQUALINI, C.D. - Experimental myocarditis induced in Swiss mice by homologous heart immunization resembles chronic experimental Chagas' heart disease. Clin Immunol Immunopathol 33: 165, 1984.

8. COSSIO, P.M.; LAGUENS, R.P.; DIEZ, C.; SZARFMAN, A.; SEGAL, A. \& ARANA, R.M. - Antibodies reacting to the plasma membrane of striated muscle and endothelial cells. Circulation 50: 1252-59, 1985.

9. CUNHA-NETO, E.; SANTANA, J. \& TEIXEIRA, A.R.L. Imunologia da doença de Chagas: história natural da interação de dois genomas eucarióticos. In: Tosta, C.E., ed. Imunologia das Infecções. Uberaba: FUNEPU 1992. p. 67-91.

10. DALE, J.B. \& BEACHEY, E.H. - Sequence of myosincrossreactive epitopes of streptococcal M protein. J Exp Med 164: 1785-1790, 1986.

11. DE LA VEGA, M.T.; DAMILANO, G. \& DIEZ, C. Leukocyte migration inhibition test with heart antigens in American Trypanosomiasis. J Parasitol 62: 129-130, 1976.

12. HARRINGTON, W.F. \& RODGERS, M.E. - Myosin. Ann Rev Biochem 53: 35-73, 1984.

13. HIGUCHI, M.L.; DE BRITO, T.; REIS, M.M.; BARBOSA, A.; BELLOTTI, G.; PEREIRA-BARRETO, A.C. \& PILEGGI, F. - Correlation between T. cruzi parasitism and myocardial inflammatory infiltrate in human chronic chagasic myocarditis: light microscopy and immunohistochemical findings. Cardiovase Pathol 2:101-6, 1993.

14. KHOURY, E.L.; DIEZ, C.; COSSIO, P.M. \& ARANA, R.M. - Heterophil nature of EVI antibody in Trypanosoma cruzi infection. Clin Immunol Immunopath 27: 283-288, 1985.

15. KIERSZEMBAUM, F. - Is there autoimmunity in Chagas' disease? Parasitol Today 1(1): 5-9, 1985. 
16. KÖBERLE, F. Cardiopatia chagásica. O Hospital 53: 311 346, 1958.

17. KOZMA, C.; JAFFÉ, R. \& JAFFÉ, W. - Estudo experimental sobre a patogenia da miocardites. Arq Bras Cardiol 13: 155 161,1960 .

18. LEVIN, M.J.; MESRI, E.; BENAROUS, C.; LEVITUS, G.; SCHIJMAN, A.; LEVY-YEYATI, P.; CHIALE, P.; RUIZ, A.; KAHN, A.; ROSENBAUM, M.; TORRES, H. \& SEGURA, E. - Identification of major Trypanosoma cruzi antigenic determinants in chronic Chagas' heart disease. Am J Trop Med Hyg 41(5);530-538, 1989.

19. MINOPRIO, P.; ITOHARA, S.; HEUSSER, C.; TONEGAWA, S. \& COUTINHO, A. - The immunobiology of murine Trypanosoma cruzi infection: the predominance of parasite-nonspecific responses and the activation of TCR1 T cells. Immunol Rev 112: 183-207, 1989.

20. MUNIZ, J. \& AZEVEDO, A.P. - Novo conceito da patogenia da "doença de Chagas" ("Tripanosomiasis americana"). Inflamação alérgica granulomatóide (A), e miocardite hiperérgica (B) produzidas em "rhesus" ("Macacca mulatta") inoculados com formas mortas de cultivo do "Schizotrypanum cruzi" (Nota prévia). O Hospital 32: 165 $183,1947$.

21. NEU, N.; BEISEL, K.; TRAYTSMAN, M.; ROSE, N. \& CRAIG, S. - Autoantibodies specific for the cardiac myosin isoform are found in mice suceptible to coxsackievirus B3induced myocarditis. J Immunol 138(8):2488-2492, 1987.

22. NEU, N.; ROSE, N.; BEISEL, K.; HERSKOWITZ, A.; GURRI-GLASS, G. \& CRAIG, S. - Cardiac myosin induces myocarditis in genetically predisposed mice. J Immunol 139(11): 3630-3636, 1987.

23. PETRY, K. \& EISEN, H. - Chagas disease: a model for the study of autoimmune diseases. Parasitol Today 5: 111-116, 1989.

24. RIBEIRO-DOS-SANTOS, R.; ROSSI, M.A.; LAUS, J.L.; SANTANA-SILVA, J.; SAVINO, W. \& MENGEL, J. - AntiCD4 treatment abrogates rejection and reestabilishes longterm tolerance to syngeneic newborn hearts grafted in mice chronically infected with Trypanosoma cruzi. J Exp Med 175: 29-39, 1992.

25. RIZZO, L.V.; CUNHA-NETO, E. \& TEIXEIRA, A. Autoimmunity in Chagas'disease: Specific inhibition of reactivity of CD4+ T cells against myosin in mice chronically infected with Trypanosoma cruzi. Infect Immun 57(9): $2640,1989$.

26. RIZZO, L.V.; MILLER-RIVERO, N.E.; CHAN, C.C.; WIGGERT, B.; NUSSENBLATT, R.B. \& CASPI, R.R. Interleukin-2 treatment potentiates induction of oral tolerance in a murine model of autoimmunity." Journal of Clinical Investigation October 1994 (in press).
27. ROSE, N.R. \& BONA, C. - Defining criteria for autoimmune diseases (Witebsky's postulates revisited). Immunol Today 14(9): 426-430, 1993.

28. SANTOS-BUCH, C.; ACOSTA, A.; ZWEERINK, H.; SADIGURSKY, M.; ANDERSEN, O.; VON KREUTER, B.; BRODSKYIN, C.; SADIGURSKY, C. \& CODY, R. - Primary muscle disease: definition of a $25 \mathrm{kDa}$ polypeptide myopathic specific Chagas antigen. Clin Immunol Immunopathol 37: 334-350, 1985.

29. SMITH, S. \& ALLEN, P. - Expression of myosin-class II major histocompatibility complexes in the normal myocardium occurs before induction of autoimune myocarditis. Proc Natl Acad Sci USA 89: 9131-9135, 1992.

30. SMITH, S. \& ALLEN, P. - Myosin-induced myocarditis is a $\mathrm{T}$ cell-mediated disease. J Immunol 147: 2141-2147.

31. TEIXEIRA, A.R.L.; CUNHA-NETO, E.; RIZZO, L.V. \& SILVA, R. - Trypanocidal nitroarene treatment of experimental Trypanosoma cruzi infection does not prevent progression of chronic-phase heart lesions in rabbits. J Infect Dis 162: 1420, 1990.

32. TEIXEIRA, A.R.L.; TEIXEIRA, G.; MACEDO, V. \& PRATA, A. - Trypanosoma cruzi-sensitized T lymphocytemediated 51-Cr release from human heart cells in Chagas' disease. Am J Trop Med Hyg 27: 123, 1978.

33. TIBBETTS, R.S.; MCCORMICK, T.S.; ROWLAND, E.C.; MILLER, S.D. \& ENGMAN, D.M. - Cardiac antigen-specific autoantibody production is associated with cardiomyopathy in Trypanosoma cruzi-infected mice. J Immunol 152: 14931499, 1994.

34. TODD, C.W.; TODD, N.R. \& GUIMARÃES, A. - Do lymphocytes from chagasic patients respond to heart antigens? Infect Immun 40(2): 832-835, 1983.

35. TORRES, C.M. - Patologia de la miocarditis crónica en la

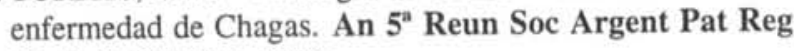
Norte 2: 902-916, 1930.

36. VAN VOORHIS, W.; SCHEKELEWY, L. \& TRONG, H. Molecular mimicry by Trypanosoma cruzi: the Fl-160 epitope that mimics mammalian nerve can be mapped to a 12 aminoacid peptide. Proc Natl Acad Sci USA 88: 5993-5997, 1991.

37. WITEBSKY, E.; ROSE, N.R.; TERPLAN, K.; PAINE, J.R. \& EGAN, R.W. - J Am Med Assoc 164: 1439-1447, 1957.

38. YAMAUCHI-TAKIHARA, K.; SOLE, M.J.; LIEW, J.; ING, D. \& LIEW, C.Y: - Characterization of human cardiac myosin heavy chain genes. Proc Natl Acad Sci USA 86:3504-3508, 1989.

39. ZHANG, J.; MEDAER, R.; STINISSEN, P.; HAFLER, D. \& RAUS, R. - MHC-restricted depletion of human myelin basic protein-reactive $\mathrm{T}$ cells by $\mathrm{T}$ cell vaccination. Science 261: 1451-1454, 1993. 